\title{
LAY MEDICAL KNOWLEDGE IN THE EIGHTEENTH CENTURY: THE EVIDENCE OF THE GENTLEMAN'S MAGAZINE
}

by

\author{
ROY PORTER*
}

Drawing attention recently in his 'Health, disease and medical care' to advances made during the last generation in the study of eighteenth-century medicine, $W$. F. Bynum also pointed to gaps remaining in our knowledge. ${ }^{1}$ One of these was the understanding of medical relations from the patient's point of view. There are two main reasons why research into lay belief-systems and practices about sickness and medicine should be a matter of moment to the medical historian. First, in "the world we have lost" the sufferer habitually played an active and sometimes a decisive role in interpreting and managing his own state of health. ${ }^{2}$ Self-diagnosis and dosing were routine amongst all ranks of society, and laymen regularly dispensed medicine to friends, family, and servants. Not least, as Jewson has explained, ${ }^{3}$ laymen also in some sense "prescribed" to the faculty: the educated and affluent sick played an assertive and sometimes even dominant role in clincial consultations. Hence, in seeking an integrated panorama of the totality of medical transactions in the community, and not least in aiming to understand the standing of the practitioner himself, we need to know what the public thought and did.4

Secondly, and more generally, we must explore lay attitudes towards health and *Roy Porter, MA, PhD, Wellcome Institute for the History of Medicine, 183 Euston Road, London, NW1 2BP.

'W. F. Bynum, 'Health, disease and medical care', in G.S. Rousseau and Roy Porter (editors), The ferment of knowledge, Cambridge University Press, 1980, pp. 211-254.

'For an introductory survey see Roy Porter, 'The patient's view: Doing medical history from below', to appear in Theory and society; for contemporary parallels see D. Locker, Symptoms and illness. The cognitive organization of disorder, London, Tavistock, 1981; A. Cartwright, Patients and their doctors, London, Royal Commission on the National Health Service, 1967; M. Balint, The doctor, the patient and his illness, London, Medical Publishing Co., 1957, 2nd ed., 1964; P.M. Strong, The ceremonial order of the clinic, London, Routledge \& Kegan Paul, 1979; D. Pendleton and J. Hasler (editors), Doctor-patient communication, London, Academic Press, 1983; C. G. Helman, "Feed a cold, starve a fever"-folk models of infection in an English suburban community, and their relation to medical treatment', Culture, Medicine and Psychiatry, 1978, 2: 107-137; for the rather sparse historical approaches see C. F. Mullett, 'The lay outlook on medicine in England, c. 1800-1850', Bull. Hist. Med., 1951, 15: 169-177; and D. Guthrie, 'The patient: a neglected factor in the history of medicine', Proc. $R$. Soc. Med., 1945, 37: $490-494$.

${ }^{3} \mathrm{~N}$. Jewson, 'Medical knowledge and the patronage system in eighteenth century England', Sociology, 1974, 8: 369-385; idem, 'The disappearance of the sick man from medical cosmology 1770-1870', ibid., 1976, 10: $225-440$.

'For backgrounds to lay initiative and English individualism see A. Macfarlane, The origins of English individualism, Oxford, Blackwell, 1978; C. B. MacPherson, The political theory of possessive individualism, Oxford, Clarendon Press, 1962; H. Perkin, The origins of modern English society, London, Routledge \& Kegan Paul, 1969; J. Thirsk, Economic policy and projects, Oxford, Clarendon Press, 1978. 


\section{Lay medical knowledge in the eighteenth century}

sickness, body and soul, living and dying - in fact, as Bynum puts it, towards "birth, copulation and death"-in order to recover contemporary values and behaviour in a wider sphere. The "new social history", sometimes drawing on anthropology, has begun to explore the mentalité of past communities regarding such vital dimensions of living as reproductive behaviour, sexuality, family formation, ${ }^{5}$ childbirth and child-rearing, old age and death, body language and expression, ${ }^{6}$ pollution and taboos, gender-relations, community care, and so forth. As the French Annales school of historians, overwhelmingly influential in pioneering these new perspectives, recognized long ago, attempts to reconstruct the fabric of customary material life will totter without an assured foundation in the understanding of beliefs and behaviour about health and sickness. In fact, French medical historians such as J.-P. Peter, Françoise Loux, Mireille Laget, and J.-P. Goubert ${ }^{7}$ have been highly innovative in probing the laity's role in the intricate networks of medical activity in pre-industrial society. And this may be one reason why other French scholars, such as Michel Foucault ${ }^{8}$ and Philippe Ariès, ${ }^{9}$ not personally within the Annales fold, have nevertheless written so stimulatingly about the power of the biomedical belief-systems of the past, set against the backcloth of the biology of man in history.

Medical history has traditionally stood in the doctor's shoes. In so doing, it has probably accurately reflected the historical community's genuine interests. ${ }^{10} \mathrm{But}$ it is also easier to practise medical history that way. The scholar can draw on a compact and easily identifiable body of printed texts about medicine written by medical notables. Lay views, by contrast, are less systematically stated and more difficult to retrieve; yet they have been preserved. For example, proverbs and sayings, rituals and riddles embalm a folklore of medicine from time past, a wisdom we might be tempted, rather anachronistically, to regard as exclusively an expression of "low culture", but which may well-at least until the watersheds of industrialization and mass literacy-have been current right up the social ladder. ${ }^{11}$ Then we also have

${ }^{5} \mathrm{~L}$. Stone, The family, sex and marriage in England, 1500-1800, London, Weidenfeld \& Nicolson, 1977; E. Shorter, The making of the modern family, London, Collins, 1976; R. Trumbach, The rise of the egalitarian family, New York, Academic Press, 1978.

'F. Bottomley, Attitudes to the body in Western Christendom, London, Lepus Books, 1979; E. J. Bristow, Vice and vigilance: purity movements in Britain since 1700, Dublin, Gill \& Macmillan, 1977 ; B. S. Turner, The body and society, Oxford, Basil Blackwell, 1984.

'See, e.g., J.-P. Goubert, Malades et médecins en Bretagne 1770-1790, Rennes, Institut Amoricain de Recherches Historiques, 1974; F. Lebrun, Les hommes et la mort en Anjou aux $17^{e}$ et $18^{e}$ siècles, Paris, Mouton, 1977. Two volumes of the Johns Hopkins 'Selections from the Annales' series present some of this material in translation: Biology of man in history, Baltimore, Md., Johns Hopkins University Press, 1975, and Medicine and society in France, Baltimore, Md., Johns Hopkins University Press, 1980, both edited by R. Forster and O. Ranum, translated by E. Forster and P. M. Ranum.

'See M. Foucault, The birth of the clinic, Eng. trans., London, Tavistock, 1973; idem, Discipline and punish, Eng. trans., London, Allen Lane, 1977.

'See P. Ariès, Centuries of childhood, London, Cape, 1962; idem, The hour of our death, London, Allen Lane, 1981.

${ }^{10}$ For critical comment see P. Wright and A. Treacher (editors), The problem of medical knowledge, Edinburgh University Press, 1982; J. Woodward and D. Richards, 'Towards a social history of medicine', in their Health care and popular medicine in nineteenth-century England, London, Croom Helm, 1977, pp. 15-55; M. Pelling, 'Medicine since 1500', in P. Corsi and P. Weindling (editors), Information sources in the history of science and medicine, London, Butterworth, 1983, pp. 379-410; C. Webster, 'The historiography of medicine', in ibid., pp. 29-43; M. Macdonald, 'Anthropological perspectives on the history of science and medicine', in ibid., pp. 61-80; and L. J. Jordanova, 'The social sciences and history of science and medicine', in ibid., pp 81-98. 


\section{R. Porter}

access to more private inventories - the reflections and decisions which sufferers set down in letters, commonplace books, journals, diaries, prayers, and the like, a record essentially confined to the literate. ${ }^{12}$ Rather more formal personal documents, preserved in public archives, can be useful too; for instance, poor-law records, court proceedings, wills, and coroners' bills, and the archives of medical charities. ${ }^{13}$ But bulking largest, the printed word is also a giant mirror of Everyreader's thoughts on health and sickness. In the seventeenth and eighteenth centuries, the common reader could find out about regimen and remedies in general interest publications such as almanacs as well as in volumes specifically devoted to medical advice, for example, John Wesley's Primitive physick. ${ }^{14}$ Books and pamphlets began to proliferate on particular topics such as venereal diseases, the regulation of diet, and the art of childbirth. For the middling classes, works such as William Buchan's Domestic medicine dispensed traditional lay medical lore mixed with élite Edinburgh therapeutics, all filtered and regularized through the pen of the trained physician. ${ }^{15}$ The early English novel, to look at another genre, shows how medical issues were often extremely close to the surface. After all, the first great English novelist was author of the Journal of the plague year; Tobias Smollett, himself a medical practitioner, made a surgeon the hero of his Roderick Random, and Laurence Sterne saturated Tristram Shandy (written "against the Spleen") with medical actions, satire, and allusions. ${ }^{16}$ The same also applies to a whole host of lesser-known fiction. Take a scene from Thomas Amory's picaresque novel, The life and opinions of John

\footnotetext{
${ }^{11}$ Much evidence is to be found in the essays in Roy Porter (editor), Patients and practitioners, Cambridge University Press, 1985. For the problem of cultural strata see P. Burke, Popular culture in early modern Europe, London, Temple Smith, 1978; D. Leith, A social history of the English, London, 1983; R. Paulson, Popular and polite art in the age of Hogarth and Fielding, Notre Dame, Indiana, and London, University of Notre Dame Press, 1979; R. Darnton, 'In search of the Enlightenment: Recent attempts to create a social history of ideas', J. mod. Hist., 1971, 43: 113-132; idem, 'The High Enlightenment and the low life of literature in pre-RevolutionaryFrance', Past and Present, 1971, no. 51, 81-115; idem, Mesmerism and the end of the Enlightenment in France, Cambridge, Mass., Harvard University Press, 1968; H. C. Payne, 'Elite versus popular mentality in the eighteenth century', Studies in eighteenth-century culture, Madison, 1979, vol. 8. pp. 201-237.

${ }^{12}$ See Joan Lane, "The doctor scolds me"... the journals and correspondence of patients in eighteenth-century England', in Porter (editor), op. cit., note 11 above. Examples would be Samuel Johnson, for whom see J. Mulhallen and D. J. M. Wright, 'Samuel Johnson: amateur physician',J. R. Soc. Med., 1983, 74: 217-222; and Alexander Pope, for whom see M. H. Nicolson and G. S. Rousseau, This long disease my life, Princeton University Press, 1968.

${ }^{13}$ See for example M. Vovelle, Mourir autrefois: attitudes collectives devant la mort aux XVIIe et XVIIIe siècles, Paris, Gallimard, 1974.

${ }^{14}$ B. Capp, Astrology and the popular press, London, Faber, 1979; G. S. Rousseau, 'John Wesley's Primitive Physick', Harvard Lib. Bull., 1968, 16: 242-256; P. Slack, 'Mirrors of health and treasuries of poor men: the uses of the vernacular medical literature of Tudor England', in C. Webster (editor), Health, medicine and mortality in the sixteenth century, Cambridge University Press, 1979, pp. 237-274; Ginnie Smith, 'Prescribing the rules of health: self-help and advice in the late eighteenth century', in Porter (editor), op. cit., note 11 above.

${ }^{15}$ C. Lawrence, 'William Buchan: Medicine laid open', Med. Hist., 1975, 19: 20-35; A.F.M. Willich, Lectures on diet and regimen, London, 1799.

${ }^{16}$ For traditional medical categories in eighteenth-century novels see R. Stephanson, 'Defoe's "malade imaginaire": The historical foundations of mental illness in Roxana', Huntingdon Lib. Quart., 1982, 45: 100-118; R. Erikson, 'Moll's fate, "Mother Midnight" and Moll Flanders', Studies in Philology, 1979, 76: 75-100; G. S. Rousseau, Tobias Smollett: essays of two decades, Edinburgh, T. Clark, 1982; Roy Porter, 'Against the spleen', in V. Grosvenor-Myer (editor), Laurence Sterne, riddles and mysteries, London, Vision, 1984, pp. 84-98.
} 


\section{Lay medical knowledge in the eighteenth century}

Buncle Esquire (1756). Paying a visit to his fiancée's father, the eponymous hero encounters him sitting reading:

As he had an Essay on fevers in his hand, when I entered the room, I requested to know how he accounted for the effects of Cantharides, in raising and strengthening a low trembling pulse, and driving the natural heat and efflatus of the blood outward, in giving relief in delirious ravings, stupors, and loss of reason, in reducing continual fevers to distinct remissions, and in cleansing and opening the obstructed glands and lymphatics, so as to bring on the critical sweats, yet loose the saliva and glandular secretions, and bring down the thick soluble urine? ...

"It is easily accounted for", replied Dr Stanvil. . . . 17

Passages such as this seem to indicate that novelists expected the Georgian fiction-reading public to be not a little au fait with medical theories.

There are, of course, pitfalls aplenty lurking ahead for the historian who hopes to put popular manuals into service as an index of what people were actually thinking and doing about their health. In the case, for example, even of a best-selling compendium of sexual advice such as Aristotle's masterpiece, we lack the evidence to say whether it was read chiefly for instruction or for titillation; did it and similar works merely summarize what oft was thought, or did it actually give people ideas? ${ }^{18}$ But one need not be a total sceptic when faced with the problems of gauging the influence of the printed word upon common consciousness, especially if one examines periodical literature. For with publications appearing regularly-every week or every month-and especially those depending upon readers for contributions and correspondence, the element of continuity and feedback ensures some real rapport between the publication and the audience (or the collapse of the organ demonstrates its absence).

One journal which did not fold was the Gentleman's Magazine.${ }^{19}$ First published in 1731 , and running continuously into the present century, it appeared monthly, and attained at its peak a circulation possibly of over 10,000 copies, and far more readers. The Gentleman's Magazine can thus safely be assumed to mirror the sober opinions of the enlightened reading élite, the catholic taste of anyone with the rank, education, or presumption to reckon himself genteel. Avoiding party politics and sectarian religious squabbles, it offered a middle-of-the-road viewpoint, reflecting moderate, enlightened common sense. ${ }^{20}$

${ }^{17}$ T. Amory, The life and opinions of John Buncle, Esquire, London, 1904, p. 431.

${ }^{18}$ D'Arcy Power, The foundations of medical history, Baltimore, Md., Williams \& Wilkins, 1931, Lecture VI, 'Aristotle's masterpiece'; J. Blackman, 'Popular theories of generation; the evolution of Aristotle's Works. The study of an anachronism', in Woodward and Richards (editors), op. cit., note 10 above, pp. 56-86; O. T. Beall, jun., 'Aristotle's masterpiece in America: a landmark in the folklore of medicine', William and Mary Quart. 3rd ser., 1963, 20: 207-222; A. McLaren, 'The pleasures of procreation', in W. F. Bynum and Roy Porter (editors), William Hunter and the eighteenth-century medical world. Cambridge University Press, 1985; Roy Porter, 'Spreading carnal knowledge or selling dirt cheap? Nicholas Venette's Conjugal love in the eighteenth century', Journal of European Studies, 1984, 14: 233-255.

${ }^{19}$ C. L. Carlson, The first magazine-a history of the Gentleman's Magazine, Providence, R. I., Brown University Studies, 1939; A. Pailler, Edward Cave et le Gentlemans Magazine (1731-54), 2 vols., Lille, 1975; A. Sullivan (editor), British literary magazines, 2 vols., Westport, Conn., Greenwood Press, 1984. For discussion of such matters as the authorship of medical articles see Roy Porter, 'Medical knowledge and the Gentleman's Magazine: Jewson revisited', in Porter (editor), op. cit., note 11 above.

${ }^{20}$ See the characterization of the "moderate Enlightenment" in H. May, The Enlightenment in America, New York, Oxford University Press, 1976. 


\section{R. Porter}

Early in the nineteenth century, the Edinburgh Review enunciated a policy of excluding medicine from its pages: "Medical subjects ought in general, we think, to be left to the Medical Journals"; it would, however, make exceptions, when, as with the issue of smallpox vaccination, they were of "incalculable importance and of such universal interest". ${ }^{21}$ But the Edinburgh's attitude of exclusion seems to mark a new departure, a sign perhaps of a growing intellectual division of labour amongst both opinion-producers and opinion-consumers, in which medicine was being set aside for specialists. Things were not so with eighteenth-century periodicals such as the Gentleman's Magazine. For the most cursory glance at its pages shows a high density of medical insertions, covering an impressive range of topics (many reprinted from other sources). Medical books were listed and reviewed;22 case histories appeared;

${ }^{21}$ Edinburgh Review, 1807, 7: 32.

"see for example this list, Gentleman's Magazine, 1736, 6: 492: PHYSICK BOOKS

1. A History of Plants growing about Paris. With their uses In Physick; and a Mechanical Account of the Operation of Medicines. Written in French. Mons. Tournetort. Translated into English with many Additions, and accommodated to the Plants growing in Great Britain. By John Martyn, F.R.S. In Two Volumes Octavo.

2. A Treatise of the Rheumatism, as well Acute as Chronical. With observations under the various Causes that may produce them: And a Method of Cure subjoined to every distinct species of that Distemper. By John Cheshire, M.B.

3. A Compendious and new Method of performing Chirurgical Operations, fit for young Surgeons-To which are added, short and easy Directions how to manage the Venereal Disease. By Edward Dunn, Surgeon, belonging to the African Company.

4. Dr Strother's Lectures on the Rationale of Medicines. Containing all that is Necessary for knowing the Virtues of Drugs already discovered, or that may hereafter be found out. In which are inserted all Simple and Compound medicines now in Use, and their Operations clearly stated. Read to Pupils, and communicated to the Publick for the Use of young Practitioners. In two Volumes.

5. Dr Strother's Essay on Sickness and Health Price 4s. 6d.

6. Criticon Febrium. Or. A Critical Essay on Fevers. price 3s. 6d.

7. Experienced Measures how to manage the Small-Pox, price $2 \mathrm{~s}$.

8. Pharmacopoeia Practica. Price 4s.

9. Practical Observations on the late Epidemical Fever, in the Year 1728, 1729; in which is contain'd a very Remarkable History of a Spotted Fever. Price 2s.

10. Dr Radcliffs Practical dispensatory: Containing a compleat Body of Prescriptions, fitted for all Diseases, Internal and External. The fifth edition. Price 5s. 6d.

11. Materia Medica: Done from the Latin of Dr. Herman. to which is prefixed, A General Introduction; containing a Mechanical Account of the Operation of Medicines upon Human Bodies. In Two Volumes, Octavo. Price 10s.

These two last publish'd by Dr. Strother. All printed for C. Rivington, at the Bible and Crown in St. Paul's Church Yard. 


\section{Lay medical knowledge in the eighteenth century}

readers wrote in with complaints about their own health, and replies were printed, giving advice and remedies; the proceedings of medical societies were scrutinized, and the founding and progress of new medical charities claimed much space. Medical "news" was also published. Thus, for example, the first account of plastic surgery to appear in England, describing the techniques as used in India, can be found in the Magazine's issue for October 1794. And, not least, a close check was kept on the health of public figures and the royal family, from the infant Prince of Wales having his hair cut, to night-by-night bulletins in $\mathbf{1 7 8 9}$ on the condition of George III in his "madness":

\section{MINUTES OF HIS MAJESTY'S INDISPOSITION}

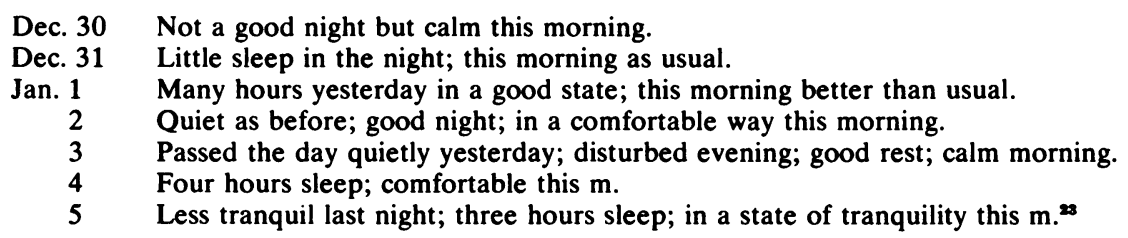

Health matters billowed into all corners of the magazine. Regular monthly items such as the printing of the London Bills of Mortality and the obituary column naturally dwelt on disease and death (as I shall explore below), but medical allusions were also prominent elsewhere. For example, the language of political polemic was drenched in medical metaphor. Reports on Parliament were not infrequently headlined "Political Physick", or given some similar medically-evocative title, and Britannia was commonly diagnosed as suffering from "constitutional clap", with "phlebotomy" being a standard prescription. ${ }^{24}$ "The nation, Sir, may be compared to a diseased Body, and we very properly be called its Physicians", opened one typical piece. ${ }^{25}$

The Gentleman's Magazine may then resemble a piece of amber, which contains trapped in its midst, for the eager historian, the everyday medical commonplaces of the Georgian educated classes. If we then examine it more closely, what specifically will it tell us about lay attitudes toward medicine at that time?

One first gets the general impression that the medical items were rather savoured. Clearly, the founder and proprietor, Edward Cave-a man noted for his astute entrepreneurial nose-and his successors thought the public wanted plenty of medical coverage ${ }^{26}$ even to the extent of reviews of rather technical anatomical and surgical publications in foreign languages. This judgement was correct, if readers'

\footnotetext{
${ }^{23}$ Gentleman's Magazine, 1789, 59: 83; for the haircut, see ibid., 1737, 7: 699; for George II's death, ibid., 1762, 32: 520.

24 Ibid., 1741, 11: 481-482; 1744, 14: 92; see P. Rogers, Grub Street, London, Methuen, 1972.

${ }^{25}$ Gentleman's Magazine, 1740, 10: 498.

${ }^{26}$ For public literary taste, see I. Watt, The rise of the novel, London, 1957; A. Cruse, The Englishman and his book in the early nineteenth century, London, Harrap, 1930; I. Rivers (editor), Books and their readers in eighteenth-century England, Leicester University Press, 1982, especially the contribution by G. S. Rousseau, 'Science books and their readers in the eighteenth century', pp. 197-256; A. S. Collins, Authorship in the days of Johnson. Being a study of the relation between author, patron, publisher and public, 1726-1780, 2 vols., London, R. Holden, 1927.
} 


\section{R. Porter}

letters are trustworthy sounding-boards, for they frequently enthuse about the value of the medical entries. N. Elles, for example, wrote in 1747 that

Amongst the agreeable variety which your Magazine contains, I shall always esteem that part the most useful, which can contribute towards relieving those whom it has pleased providence to afflict with sickness .... [To which the editorial response was:] To find that we have in any degree contributed to the benefit of the public, or of any individual, gives us great pleasure; and we publish the above letter that those gentlemen, who have furnished any of the matters hinted at, may share in it, and be further encouraged to communicate useful designs etc. ${ }^{27}$

In a similar vein "R.B." wrote in 1754:

I am pleased to observe the increase in your medical correspondents, by whom the publick must be great gainers ... [there are many sorts of interesting essays in the magazine but] none ought to be more esteemed than those that contribute to the knowledge and removal of those causes that obstruct the health of mankind. ${ }^{28}$

Such sentiments recur time and again. In 1800 , for example, the secretary of the Humane Society addressed the editor:

Mr. Urban, Spital-square, April 18.

As you have made an appearance for more than half a century, and gained meritoriously the approbation of the medical, philosophical, and ingenious part of mankind; as, in those various branches, you have tended much to the advancement of science; it appears to me, an insertion of the following novel instance of Revivication should be in your valuable Repository. W. HAWES. ${ }^{20}$

Out of this general enthusiasm for the magazine's function as a medical talking-shop and organ for diffusing knowledge arose a suggestion for a more formal medical corner, a regular column whose entries would be regulated by stated criteria:

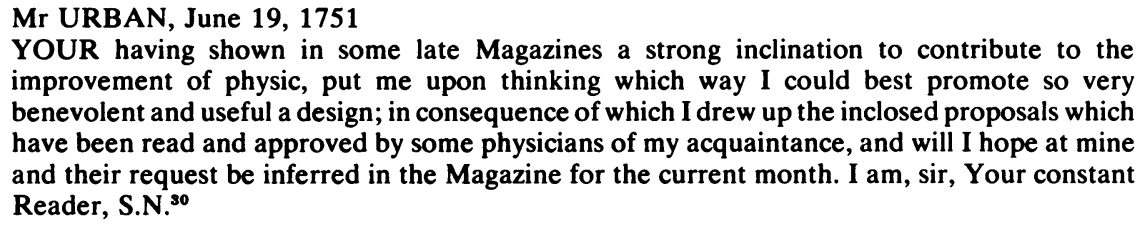
improvement of physic, put me upon thinking which way I could best promote so very benevolent and useful a design; in consequence of which I drew up the inclosed proposals which have been read and approved by some physicians of my acquaintance, and will I hope at mine and their request be inferred in the Magazine for the current month. I am, sir, Your constant Reader, S.N. ${ }^{30}$

"S.N." listed his specifications for a regular, orderly, medical correspondence. Perhaps these were too regimented for the gentlemanly traditions of English liberty; certainly, nothing came of his recommendation. But the Magazine's pages continued to be the vehicle not just for routine medical news and questions-and-answers about diagnosis and prescription, but also for wider initiatives and impulses of health-conscious public spirit. For instance, following the voicing of grumbles to the effect that marketing secret nostrums constituted a quack practice contrary to the public interest (knowledge should be public not private), ${ }^{31}$ one contributor took the

${ }^{27}$ Gentleman's magazine, 1747, 17: 77.

${ }^{28}$ Ibid., 1754, 24: 362.

so Ibid., 1800, 70: 334. Cave had pseudonymously christened the editor of the Magazine "Sylvanus Urban".

${ }^{30}$ Ibid., 1731, 21: 308 .

s1 Ibid., 1734, 4: 616; 1735, 5: 10. 


\section{Lay medical knowledge in the eighteenth century}

trouble to compile an impressively comprehensive table of the range of nostrums offered for sale, listing their proprietors, where they could be bought, the complaints for which they were specifics, and the proper price (see Appendix). ${ }^{32}$

The readership, thus, seems to have welcomed items about health. This interest is perhaps reflected in the frequent publication of verse on this subject. As in contemporary anthologies, there are, of course, plenty of genre pieces about death, as also poems rendering thanks for recovery from sickness. But in addition, there are more specifically medical items. Some gave treatments in verse, such as this one on asthma, characteristically recommending regimen and moderation:

\section{RECIPE FOR an ASTHMA}

My good old friend! accept from me The following rules without a fee. An asthma is your case, I think, So you must neither eat nor drink; I mean of meat preserv'd in salt, Or any liquor made of malt.

From season'd sauce avert your eyes, From hams, and tongues, and pigeon pies. If ven'son pasty's set before ye, Each bit you eat memento mori. Now as to liquor, why, indeed What I advise, I send you, mead. Glasses of this t' extinguish drought, Take three with water, three without. Let constant exercise be try'd And sometimes walk, and sometimes ride:

Health oftner comes from Blackdown hill Than from th' apothecary's bill. Be not in haste, nor think to do Your bus'ness with a purge or two; Some, if they are not well at once, Proclaim their doctor for a dunce;

Restless from quack to quack they range, When 'tis themselves they ought to change; Nature hates violence and force, By method led and gentle course, Rules and restraint you must endure, What comes by time 'tis time must cure. The use of vegetables try, And prize Pomona in a pye.

Whate'er you eat put something good in, And worship Ceres in a pudding, Young Bacchus' rites you must avoid, And Venus must go unenjoy'd

Thus may you laugh, look clear and thrive, Enrich'd by those whom you survive. ${ }^{33}$

But many general addresses to Health were printed as well, usually invocations praying for its return:

\footnotetext{
s2 Ibid., 1748, 18: 346.
}

${ }^{33}$ Ibid., 1751, 20: 84. 


\section{R. Porter}

\section{ODE to HEALTH}

Come rosy health, celestial maid, Why this delay to yield me aid? Swift from the rural cell advance. The rural cell of temperance, For well I trow in such a cell, And not in courts thou lov'st to dwell.

Fair sources whence all our pleasures spring, Come rosy health, and with thee bring The gallant eve chearful crew, Of youthful joys, thy offspring true.

At thy appearance black Despair With Pain stalks off, a sullen pair, Pale Fear of Melancholy bred, Sickness that hangs the drooping head, Slowly retreat; ${ }^{34}$

These slightly outnumber hymns celebrating its joyous presence along the lines of the following:

\section{ODE to HEALTH}

Hail rosy Health, celestial, blooming Fair, Offspring of Temperance, Virtue's sweetest child, And soft Content, that smooths the brow of Care, Parent of Joy and Pleasure ever mild. I feel thy influence, life-bestowing pow'r While the warm tide glides swiftly through my veins; And while reclin'd in blooming Hebe's bow'r I consecrate to thee the living strains. ${ }^{35}$

Such effusions are, of course, platitudinous. But even in their conventionality they may reflect the new turn of sentiment in the age of enlighenment away from traditional Christian preoccupations with the corruption and mortification of the flesh and with the afterlife (what Louis Martz called "the poetry of meditation"), ${ }^{36}$ abandoning also the aristocratic punctilio about the purity of blood. The typical clichés reveal instead more secular and individualistic visions of personal health and happiness as the summum bonum. ${ }^{37}$ Moreover, such verse does not simply apostrophize health in the abstract, but usually proffers self-physicking advice as to how to secure and improve it, as in these lines which "confirm the truth Hippocrates decrees":

\section{THE ECONOMY OF LIFE}

\section{(BY DR. CRANE)}

Be cautious of extremes in all you do,

And still through life a middle course pursue

\footnotetext{
34 Ibid., 1759, 29: 334.

${ }^{36}$ Ibid., 1767, 37: 517.

${ }^{36}$ Bottomley, op. cit., note 6 above; Roy Porter, 'Mixed feelings: the Enlightenment and sexuality in eighteenth-century England', in P.-G. Boucé, (editor), Sexuality in eighteenth-century Britain, Manchester University Press, 1982, pp. 1-27.

${ }^{37}$ Foucault argued that health became to the bourgeoisie what blood had been to aristocrats. $M$. Foucault, $\boldsymbol{A}$ History of sexuality, vol. 1. Introduction, London, Pantheon Books, 1979; L. Martz, The poetry of meditation, New Haven, Conn., Yale University Press, 1962.
} 


\section{Lay medical knowledge in the eighteenth century}

Avoid Repletion, Mammon's baneful curse, But Inanition more-for, that's still worse; The first by nature or by art is cur'd,

The last a longer time must be endur'd, 'Tis easier to deplete the loaded frame, Than, when exhausted, to recruit the same; Hence the robust in health by art are lower'd Much sooner than the weak can be restor'd Whene'er invited to the sumptuous feast, Of two prevailing evils choose the least; Gluttons incur more danger when they dine Than what results from an excess in wine; Extremes in both by prudent men are shunn'd, Who squander not in early life that fund Of health-on which in future they rely, The blest resource of late infirmity ....38

Though those lines were penned by a physician, the Gentleman's Magazine's medical verse does not typically view health as lying in the gift of the faculty, but sees it rather as hinging on self-management and temperance of body and mind. It may be significant that amongst the few poems offering thanks to a particular physician for recovery, one is to a "mad-doctor":

\section{STANZAS OF GRATITUDE}

Addressed to Dr. WILLIAM PERFECT, of West Malling; who restored the Author from the most wild and frantic Madness, to cool Sense and rational Judgement.

O PERFECT, with power divine You all my wreck'd senses repair'd! Such bays for thy brows let me twine, As truth and respect have prepar'd.

My feelings and reason, when tost In the ocean of rage, your kind care Prevented my bark being lost, And dash'd on the rocks of despair.

My ideas derang'd and misled, Hygeia you led by the hand, Her poppies around me she shed, And bade my lost reason expand.

Thus charm'd my lost senses return'd To their seats once again in array; From darkness the change I discern'd, With intellect bright as the day.

Now blithely o'er nature I roam, As the lark at the dawn I am gay; And rest myself happy at home, Delighted this tribute to pay. CYNTHIUS, ${ }^{30}$

${ }^{38}$ Gentleman's Magazine, 1795, 65: 948.

${ }^{39}$ Ibid., 1788, 58: 916. 


\section{R. Porter}

The implication, perhaps, is that the rational and sane man should endeavour to be his own physician and see prevention as better than cure; but once he has lost his mind, he has also lost his power for medical self-help.

Physicians are not, it would seem, pivotal figures in the models of healing presented in the magazine. But that is not to say that rational, scientific medicine is in any way discounted in favour of radical therapeutic alternatives. Far from it. The general tone of Gentleman's Magazine contributions is one of accepting modern regular physick as part of rational enlightenment. Items were inserted reporting, and even occasionally endorsing, medical "superstitions". Thus: "Ramsey in Huntingdonshire. At Mr Smiths a Farmer here, is a Rookery, in which are many Nests of young Birds, ready to fly. The same thing happened about 80 years ago, after which a great and fatal Sickness spread thro' that and the adjacent Villages, . . ."40 But such superstitions generally got a bad press. ${ }^{41}$ Faith in "holy oil" as a cure-all, for instance, got short shrift as both popish and vulgar:

Mr Urban, Colchester, Nov. 10.

The pretended miraculous cure of Anne Mannings, inserted in your last magazine. (see p. 458-9) is, among many others which this age and nation hath lately produced, a glaring proof of the superstitious credulity of the lower class of people, who are ever ready to entertain and believe the grossest absurdities. ${ }^{42}$

Similarly, a travelling healer who claimed to cure the "King's Evil" was exposed by a reader as a clandestine Jesuit or Jacobite, ${ }^{43}$ while, at the other religious extreme, a work of comfort for the sick in time of tribulation was denounced as Methodistic: clearly, it was thought that there were healthier and worthier things for the sick to have on their minds than hellfire and repentance. ${ }^{44}$ The mere fact that the lay readership took an active interest in physick clearly does not automatically entail that the laity was cultivating a medical alternative to that of the regular faculty. The roots of "fringe" medicine are another issue entirely.

In this paper I shall not attempt doggedly to plot, item by item, the entire coverage of medical topics provided by the Gentleman's Magazine, or even those contributions

${ }^{40}$ Ibid., 1737, 7: 703; for the same theme compare $1748,18: 448-450$. For a report of a monstrous birth resulting from the mother's imagination, see 1746, 16: 270 :

\section{Monday April 28}

The wife of one Rich. Haynes of Chelsea, aged 35 and mother of 16 fine children, was deliver'd of a monster, with nose and eyes like a lyon, no palate to the mouth, hair on the shoulders, claws like a lion instead of fingers, no breast-bone, something surprising out of the navel as big as an egg, and one foot longer than the other.-She had been to see the lions in the Tower, where she was much terrify'd with the old lion's noise.

${ }^{41}$ For eighteenth-century repudiation of previous fascination with monsters see K. Park and L. Daston, 'Unnatural conceptions: the study of monsters in sixteenth-century France and England', Past and Present, 1981, no. 92, 20-54; C. J. S. Thompson, The mystery and lore of monsters, London, Williams \& Norgate, 1930; K. Thomas, Religion and the decline of magic, London, Weidenfeld \& Nicolson, 1971.

${ }^{42}$ Gentleman's Magazine, 1751, 21: 503.

${ }^{43}$ Ibid., 1751, 21: 414. See more generally M. Bloch, The royal touch, London, Routledge \& Kegan Paul, 1973.

${ }^{44}$ Gentleman's Magazine, 1788, 58: 816. 


\section{Lay medical knowledge in the eighteenth century}

penned by the laity. I shall instead try to highlight typical knots of interests. Numerically speaking, the most prominent of these was the request for, and exchange of, practical remedies for specific ills, to relieve personal suffering; for, as one correspondent put it, the "immediate object" is to supply information which will "tend to the cure" of disease. ${ }^{45}$ It was the generally unspoken assumption of the contributors that the common reader was likely to be prescribing for himself and his circle. Occasionally, this was actually stated in so many words. Thus in 1767 , a correspondent offered "A method to cure, or at least to prevent, the increase of any naval [sic] rupture"-which he claimed was all the more useful because it was by "a bandage which any one may make themselves". ${ }^{46}$ Similar do-it-yourself dispensing was in the mind of the reviewer of the New Edinburgh pharmacopoeia in 1800 . In selecting extracts from this work, he chose to include tables of dosage, commenting: "THIS is an extremely useful little manual; and the following Table, designed to shew the doses of medicine proper for persons at different ages, cannot but be acceptable to such of our country readers as attend to the relief of their distressed neighbours in a period of sickness"47

In number after number of the Magazine, one is bombarded by requests for medical advice: ${ }^{48}$ how do you cure corns? ${ }^{49}$ or get rid of chilblains $?^{50}$ or relieve cramp $?^{51}$ How do you purge worms $?^{52}$ treat viper bites ${ }^{53}$ How do you grow senna? ${ }^{54}$ Sometimes what is sought is not a remedy but rather an explanation: why is it believed that a good antidote to excessive water retention is to apply a live toad to the region of the kidneys? ${ }^{55}$

Many of these queries duly received their reply from other readers. For instance, in response to a plea from an asthma sufferer, an answer winged in from $\mathrm{H}$. Mugg, who had culled some of his advice from Dr Monro and Culpeper but who chiefly relied on personal experience:

Mr. Urban, Chudleigh, Feb 22.

FOR the satisfaction of a constant Reader, who, p. 66, requests to know if there be any simple but effectual cure for an asthma; I take the liberty to trouble you with the following remarkable instances of the good effects of honey in asthmatic cases, as related by Dr. Monro; and sincerely

${ }^{45}$ Ibid., 1771, 41: 156.

${ }^{46}$ Ibid., 1767, 37: 347:

P.S. As it is supposed nothing very like the bandage herein described, has ever yet appeared in publick, it is desired, if you approve of it, that you will give it a place in your useful Magazine, for the sake of the public good; the person who sends it you, having experienced the utility of it for a great many years past, is unwilling that so simple, and yet so effectual a remedy should die with him.

${ }^{47}$ Ibid., 1800, 70: 255.

"Gilbert D. McEwen, The oracle of the coffee-houses. John Dunton's "Athenian Mercury", San Marino, Calif., The Huntington Library, 1972.

${ }^{49}$ Gentleman's Magazine, 1793, 63: 129.

${ }^{50}$ Ibid., 1749, 19: 523.

${ }^{51}$ Ibid., 1800, 70: 66.

52 Ibid., 1792, 62: 1082 .

ss Ibid., 1738, 8: 523.

${ }^{54}$ Ibid., 1798, 68: 463-464.

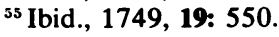




\section{R. Porter}

with that a fair trial of it may be attended with a farther confirmation of its utility in relieving that dreadful malady. ${ }^{56}$

Having recommended the herb horehound, the correspondent concluded: "From the experience I have had of it on myself, in my own family, and others, I am sure that I am justified in thus recommending it, as well as Culpepper [sic], from whom I originally had it, and whom others will do well to consult. H. MUGG."

Indeed, subscribers quite frequently sent in remedies garnered from their medical reading. Answering the query about purging worms, a reader copied out a treatment of Dr William Heberden ${ }^{57}$ But such remedies taken from medical publications nestle cheek-by-jowl with folk and herbal recipies, letters from the laity alongside prescriptions from practitioners. In answer to the query on cramp, answers poured in from "G.H." ("I am no physician"), and from "Meanwell", but also from Dr Lobb. ${ }^{58}$ There is little to choose between them. As filtered through the Gentleman's Magazine, the world of medical discussion and information seems inclusive and comprehensive rather than rigidly stratified according to professional demarcations.

Futhermore, hundreds of other remedies were sent in by laymen off their own bat-cures for colds and coughs, for the bloody flux, for sea-sickness, ${ }^{59}$ for worms, ${ }^{60}$ for scalds (cold water), ${ }^{61}$ for sprains,${ }^{62}$ for the stone,${ }^{63}$-in addition to admonitions on the dangers of sea-bathing, for example. ${ }^{84}$ Cures were not exempt from fashion. Certain treatments-such as Bishop Berkeley's tar water-clearly enjoyed a temporary vogue. ${ }^{65}$

There is a certain pattern visible in the characteristic ailments for which relief was sought. There are relatively few requests for treatments for the great killer complaints: consumption, malignant fevers, apoplexy, child-bed and infant fevers, or for other desperate chronic or fatal conditions such as madness or cancers. Neither did many correspondents seek remedies for ailments such as dropsy, for which standard surgical procedures existed, and it is noteworthy that there were no requests for venereal disease cures, though this absence was presumably due to modesty. ${ }^{66}$

${ }^{56}$ Ibid., 1800, 70: 329.

${ }^{57}$ Ibid., 1792, 62: 1082. Similarly, a cure for leg ulcers is offered which was reprinted from Medical Observations and Inquiries, 1757, 1: 286-295. See Gentleman's Magazine, 1757, $27: 397$.

${ }^{58}$ Ibid., 1762, 32: 218-219, 232, 210-212.

${ }^{59}$ Ibid., 1747, 17: 31.

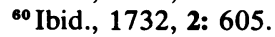

${ }^{61}$ Ibid., 1793, 63: 1076

62 Ibid., 1740, 10: 35.

${ }^{63}$ Ibid., 1751, $21: 497$.

${ }^{64}$ Ibid., 1786, 56: 1035-1036.

${ }^{65}$ M. H. Nicolson and G. S. Rousseau, 'Bishop Berkeley and tar water', in H. K. Miller (editor), The Augustan milieu, Oxford, Clarendon Press, 1970, pp. 102-137; cf. Gentleman's Magazine, 1745, 15: 77; 1748, 18: 485; etc.

${ }^{66}$ H. MacGregor, 'Eighteenth-century V.D. publicity', Br. J. vener. Dis., 1955, 31: 117-118. Being a "gentleman's magazine" it is hardly surprising that it carries almost no discussion of "female complaints", for which see A. G. Debus, 'Scientific truth, and occult tradition: the medical world of Ebenezer Sibly (1751-99)', Med. Hist., 1982, 26: 259-278; A. Comfort, The anxiety makers, London, Nelson, 1967. Also conspicuous by their absence are the nervous complaints. Was the Gentleman's Magazine rather too sober an organ for these cosmetic afflictions? For the cultural history of these complaints see Roy Porter, 'The rage of party: A glorious revolution in English psychiatry?', Med. Hist., 1983, 27: 35-50; G. S. Rousseau, 'Nerves, spirits and fibres: towards defining the origins of sensibility, with a postscript 1976', in The Blue Guitar, 1976, 125-53; 1972, 391-401; idem, 'Science and the discovery of the imagination in 


\section{Lay medical knowledge in the eighteenth century}

One may guess that readers either were inured to living with-and dying of-these critical conditions, or expected to receive regular treatment from physicians and surgeons. By contrast, the great majority of afflictions for which relief was sought consisted of the routine painful maladies and degenerative afflictions which healthy people could expect from time to time, causing suffering, inconvenience, and debility-complaints such as cramp, asthma, coughs, gravel, the stone, and gout. Furthermore, the problems of coping with accidents and occupational and environmental dangers were also prominent, reminding us of the vulnerability of the human frame in an agricultural and workshop economy heavily dependent on muscle power, and in a society where there were no legislative safeguards or inspections for occupational safety, few "casualty wards", and no "ambulances" to whisk accident victims off to hospital. There are scores of entries offering "first-aid" tips and giving advice as to how to deal with such crises as accidental poisonings caused by people eating toadstools ${ }^{67}$ or plants like gentian root, ${ }^{88}$ or swallowing arsenic poison ${ }^{69}$ put down for vermin. Snake bites are common, ${ }^{70}$ as are injuries sustained on the farm. ${ }^{71}$ And great space is given over to bites by mad dogs and other conditions transmitted from livestock and domestic animals to humans. Presumably because of the horrifying nature of the symptoms and the certainty of death, many a correspondent felt the dictates of humanity obliged him to venture yet another hopeful cure for hydrophobia. ${ }^{72}$

Thus the pages of the Gentleman's Magazine give a direct impulse to the relief of suffering, sustained by a paternalistic sense of responsibility for the welfare of friends and familiars, kith and kin. Sometimes this rises to more general expression of concern for the health of communities. We must, however, avoid anachronism. There are hardly any harbingers of the characteristic campaigns of the Victorian age - the crusades for public health, sanitary reform, occupational regulation, environmental inspection, the scandalized investigations into the diseases of the labouring dangerous classes; neither are there calls for legislative intervention. Rather, what these scores of Gentleman's Magazine articles reveal is a sustained interest-both intellectual and practica-in understanding the relations between personal sickness and environment.

The theoretical matrix for this was the ingrained Hippocratic leanings of the Enlightenment gentleman. ${ }^{73}$ Aware of the non-naturals, educated opinion recognized that individual well-being hinged to a large extent upon environment, and that ill health was fomented by miasma from pestilential locations, by atmospheric

\footnotetext{
Enlightenment England', Eighteenth-Century Studies, 1969, 3: 108-135; E. Fischer-Homberger, 'Hypochondriasis of the eighteenth century. Neurosis of the present century', Bull. Hist. Med., 1972. 46: $391-401$.

${ }^{67}$ Gentleman's Magazine, 1767, 37: 488.

${ }^{68}$ Ibid., 1748, 18: 118.

${ }^{69}$ Ibid., 1762, 32: 386 .

${ }^{70}$ Ibid., 1738, 8: 416; 1798, 58: 392; 1798, 68: 479.

${ }^{71}$ Ibid., 1749, 19: 407.

${ }^{72}$ C. Mullett, 'Hydrophobia: its history in England to 1800', Bull. Hist. Med., 1945, 18: 44-65. See Gentleman's Magazine, 1752, 22: 318, 571, 619; 1754, 24: 362; etc.

${ }^{73}$ See L. J. Jordanova, 'Earth science and environmental medicine: the synthesis of the late Enlightenment', in L. J. Jordanova and Roy Porter (editors), Images of the earth, Chalfont St Giles, British
} 


\section{R. Porter}

effluvia, and by the elements. Each issue of the Gentleman's Magazine carried a digest of the previous month's weather, giving details of thermometer and barometer readings and noting levels of sunshine, rainfall, etc. And as a regular part of the weather report, outbreaks of infections, both of humans and livestock, were analysed in their relations to climate, and predictions made of likely future epidemics and seasonal health risks. For instance, the weather column for October 1752 notes about London:

\footnotetext{
The town in general has been healthy, as from so equal a season might be expected; some inflammatory disorders of the bowels have occur'd but oftener occasioned by errors in diet, especially the eating of vast quantities of walnuts, which are uncommonly plentiful, than by any other cause.

And here it may not be improper to observe that this nut seems entirely indigestible in the stomach unless it be first well chew'd, and by the teeth ground down as fine as it ought to be to become nutritious. Without this care it breaks under the teeth into small angular bits, often with sharp edges capable of hurting very tender bowels, and by this means, and not by any acid, irritating quality, they are naturally possess'd of while recent, occasioning pains, sometimes fluxes, or spasmodick constrictions of the guts, and obstinate costiveness. ${ }^{74}$
}

Stimulated perhaps by the meteorological column, numerous correspondents (including the eminent $\mathrm{Dr}$ Fothergill) called for better weather data, ${ }^{75}$ and speculated on the links between climate and sickness. For example, "F.Y." observed in 1783 that "the intemperature of the air is the principal cause to which we may ascribe the present epidemical disorder", but also pointedly attributed the "putrescent air" to recent man-made environmental changes such as "the number of enclosures, and the many inland cuts made for navigation". ${ }^{78}$ Similarly, the review of Dr Rutty's Chronological history of the weather and diseases in Dublin called for weather tables to be kept "from generation to generation", even while resignedly concluding that such knowledge might do little good unless "weather was in the power of the physician"-a suggestion perhaps echoing the fable of the megalomaniac astronomer in Rasselas. ${ }^{77}$

The need for improved collection and presentation of vital statistics was a frequent call in the magazine. Reflecting on the Bills of Mortality, published monthly in the magazine, several correspondents wanted more informative breakdowns of causes of death, and "LANCASTRENSIS" argued the need for the "establishment of a medical topography in this kingdom", citing Moss's A familiar medical survey of Liverpool (1784) as his model. ${ }^{78}$

Such advances in knowledge would be the spur to action; and the pages of the Magazine give copious illustration of readers' active involvement in practical health initiatives. These took many forms. One was enthusiasm for smallpox inoculation. The advent of inoculation roused moral debate and religious scruples in Georgian England, and these were aired in the pages of the Magazine. ${ }^{79} \mathrm{~A}$ typically worried

Society for the History of Science, 1979, pp. 119-146; C. J. Glacken, Traces on the Rhodian shore, Berkeley, University of California Press, 1967.

${ }^{74}$ Gentleman's Magazine, 1752, 22: 443.

${ }^{75}$ Ibid., 1771, 41: 156-158.

${ }^{76}$ Ibid., 1783, 53: 920.

${ }^{77}$ Ibid., 1771, 41: 36. See S. Johnson, Rasselas, London, R. \& J. Dodsley, 1759, chs xl-xliii.

${ }^{78}$ Gentleman's Magazine, 1788, 58: 592.

${ }^{79}$ For the inoculation debates see A. D. Farr, 'Medical developments and religious belief, with special reference to Europe in the eighteenth and nineteenth centuries', Open University PhD thesis, 1977. 


\section{Lay medical knowledge in the eighteenth century}

Enlightenment father wrote in to seek guidance as to whether-now that fathers had ceased to be Filmerian patriarchs, becoming instead Lockian trustees to their offspring - a parent, in fact, had the right to inflict the minor illness caused by inoculation on his child, who necessarily could not give consent. ${ }^{80}$ And the Magazine printed a few items expressing religious opposition to variolation, alleging that it was unnatural and impious to inflict disease unnecessarily, and possibly dangerous, on healthy people. Yet the bulk of entries supported inoculation-as did the occasional editorial intervention. ${ }^{81}$ Indeed, the Magazine gave its blessing, though in rather qualified terms, to the Suttonian technique of inoculation, and, in addition, lent its support to smallpox charities for the poor, on the grounds that inoculation was useful only if performed en masse throughout a community, which poorer members clearly could not afford. ${ }^{82}$

Gentleman's Magazine readers gazed out into the community; they saw suffering, much of it inflicted by ignorance or bad habit, and thus unnecessary and remediable; and they urged steps to relieve it, by intellectual enlightenment and positive action. From time to time, articles spoke out against archaic and unnatural child-rearing practices (swaddling was condemned, ${ }^{83}$ breast-feeding advocated ${ }^{84}$ ), and against the tight-lacing of young women. ${ }^{85}$ From similar liberal socio-moral perspectives, contributors expressed sympathetic attitudes towards suicides, above all attacking the barbarity of the laws which ruled a suicide's property forfeit. Humane and practical alternatives were suggested:

The extreme and evident cruelty of this law has produced an almost constant evasion of it, though it can be no otherwise evaded by perjury; and the coroner's jury generally find the suicide a lunatic, though there is no other evidence of his lunacy than his crime. I therefore propose that the goods and chattels of the suicide belong to his legal representatives and that whether lunatic or not lunatic, the body be delivered for dissection, either to the surgeons company, or to such persons as read private lectures, who shall take such bodies by rotation, entering their names with the coroner of the country for that purpose. ${ }^{86}$

${ }^{80}$ Gentleman's Magazine, 1752, 22: 126.

${ }^{81}$ Ibid., 1752, 22: 209; 1751, 21: 152. The editor, after printing a letter opposed to smallpox inoculation, replies:

It is presumed that in the first transport of grief for the loss of an amiable infant, the writer of this letter concludes too hastily: For the success of inoculation in Durham, according to his account, is very different from the experience of every other place; we wish however that every instance of ill success that occurs in the practice of this new fashionable operation with the circumstances and causes, as far as they can be known, may be communicated to the public.

For the popularization of inoculation in England, see G. Miller, The adoption of inoculation for smallpox in England and France, Philadelphia, University of Pennsylvania Press, 1957.

${ }_{82}$ Gentleman's Magazine, 1767, 37: 68. See P. Razzell, The conquest of smallpox, Firle, Sussex, Caliban Books, 1977; idem, Edward Jenner's cowpox vaccine: The history of a medical myth, Firle, Sussex, Caliban Books, 1977.

${ }^{83}$ Gentleman's Magazine, 1743, 13: 432.

${ }^{84}$ Ibid., 1782, 52: 507; see E. Caulfield, The infant welfare movement in the eighteenth century, New York, Hoeber, 1931; Stone, op. cit., note 5 above.

${ }^{85}$ Gentleman's Magazine, 1743, 13: 430.

${ }^{86}$ Ibid., 1754, 24: 506. On eighteenth-century attitudes to suicide see G. Noon, 'On suicide', J. Hist. Ideas, 1978, 39: 371-386; Lester G. Crocker, 'The discussion of suicide in the eighteenth century', ibid., 1952, 13: 47-72; S. E. Sprott, The English debate on suicide, Le Salle, Ill., 1961. 


\section{R. Porter}

Furthermore, the pages of the Magazine were used to mobilize direct action. Many good causes were publicized: for instance, attempts to float schools for the deaf and dumb ${ }^{87}$ and it is, maybe, worth noting that Samuel Johnson, one-time Gentleman's Magazine contributor, regarded the presence of such a school in Edinburgh as the true beacon of the Scottish Enlightenment: "It was pleasing to see [Johnson wrote at the end of his tour] one of the most desperate of human calamities capable of so much help: whatever enlarges hope, will exalt courage; after having seen the deaf taught arithmetick, who would be afraid to cultivate the Hebrides?"8s Both the Foundling Hospital ${ }^{89}$ and the Magdalen Charity for Reformed Prostitutes received encouragement within the Magazine. And it was in the pages of the Gentleman's Magazine that the evils of private lunatic asylums were first exposed, and calls made for legislation and inspection to prevent improper confinement and scandalous treatment. ${ }^{90}$ But two campaigns received particular attention.

First, proponents of voluntary hospitals made full use of the pages of the Gentleman's Magazine for publicity. Comment in the Magazine on the sundry plans to establish provincial philanthropic hospitals was uniformly favourable, with regular fanfares about the general utility and benefits of such "humane and laudable" establishments, exemplified in this proposal of $\mathbf{1 7 4 1}$ for establishing a hospital:

I A public Hospital is the only certain way of relieving the Poor-Sick; who are frequently neglected and over-looked at their own Homes; because Physicians and Surgeons can neither give their Attendance, nor dispense their medicines with any Convenience at more Places than one; and because their Concerns are of too private a Nature to engage the Attendance of any, but the very Few who make it their business to inquire after them.

II It is the most safe and eligible manner of doing it; because the Care and Neatness as well as the Simplicity and Regularity of Diet with which the Poor are kept in an Hospital, do all contribute much sooner to their Recovery, than their own way of living; and are often more effectual than Physic, in the Cure of several of the most inveterate Distempers.

III The Expense of relieving a great Number of Sick Persons in any Hospital, bears no proportion to that of assisting them at their respective Homes: And the Widow's Mite instrusted with those who can dispose of it in this way will go farther towards answering the Ends of Charity, than a sum of Money bestow'd at random, on such, as are incompetent Judges of the Use of it, or of the proper Manner of laying it out.

IV It opens a channel for private Charities which have been long wanted, and enables Persons to lay them out to certain Advantage; because everyone has it in his Power from the moment he subscribes to recommend a

\footnotetext{
${ }^{87}$ Gentleman's Magazine, 1753, 23: 769; 1754, $24: 506$.

sa Samuel Johnson, A journey to the Western Isles, New Haven, Conn., Yale University Press, 1971, p. 148; E. A. Bloom, Johnson in Grub Street, Providence, R. I., Brown University Press, 1957.

${ }^{80}$ Gentleman's Magazine, 1734, 4: 558; 1765, 35: 475; 1759, 29: 233.

${ }^{80}$ Ibid., 1763, 33: 25-26.
} 


\title{
Lay medical knowledge in the eighteenth century
}

\author{
Patient, and by that means may be assured, that his \\ Bounty cannot be misapplied:.... \\ VIII It provides for the Relief and Comfort of Multitudes \\ who are unable to be at the Expense of Advice or \\ Physick, but are not distinguished by the Name of The \\ Poor, because they do not come under the Care of a \\ Parish or Workhouse; and yet are most of all entitled \\ to the Regards of the Public; since they are in present \\ Want; and are of the Diligent and Industrious, which is \\ the most useful and valuable Part of all Society. ${ }^{91}$
}

The details of schemes for the establishment of provincial hospitals, such as the Berkshire County Infirmary, ${ }^{92}$ were reprinted, as were poems urging potential donors to subscribe ("Hail, gen'rous BERKSHIRE"), ${ }^{93}$ and notices reminding subscribers that contributions were due $!^{94}$ And the handsome gifts of philanthropists got prominent attention. Several hospitals inserted their rules in the Magazine, ${ }^{95}$ presumably for the benefit of parish officers and JPs needing to know the terms of eligibility for the poor. Others, such as the Winchester, published annual reports, proudly listing their cure rates, and including financial accounts. ${ }^{96}$ One remarkable feature of the voluntary hospital movement in the provinces in Georgian England is their great uniformity of plan. This may well have owed something to the power of the Gentleman's Magazine as a publicity organ.

What is conspicuous is that items about hospitals were angled almost wholly towards their public and philanthropic face, rather than their medical regime. The magazine carried no discussions about the therapeutics offered by hospitals (though one item investigated how the buildings might be made more wholesome ${ }^{97}$ ). Rather, it was information and issues regarding government, finance, and the terms of admission that cropped up again and again in print. Not, however, that they were controversial: such reports are bathed in a consensual glow of benevolence. Indeed, the hospital appears in the Gentleman's Magazine as the sublime expression of lay charity directed towards the relief of the sick. ${ }^{\mathbf{9}}$

A parallel is visible in the way Gentleman's Magazine contributors drummed up support for that other typical eighteenth-century enthusiasm, the "humane movement" for the resuscitation of the "dead", in particular the "drowned". The obituary columns of the Magazine paradoxically confirm how lethal water was to Britannia. It is not surprising that a maritime and naval power, so dependent upon rivers for transport and haulage, should have witnessed so many drowning accidents, particularly with the coming of canal mania in the second half of the century-though

\footnotetext{
${ }^{91}$ Ibid., 1741, 11: 476. These points are taken from the publicity for the Devon and Exeter Hosptial.

${ }^{92}$ Ibid., 1744, 14: 52.

${ }^{93}$ Ibid., 1744, 14: 47.

${ }^{94}$ Ibid., 1741, 11: 568 .

${ }^{95}$ Ibid., 1741, 11: 474, 652.

${ }^{96}$ Ibid., 1744, 14: 52.

${ }^{97}$ Ibid., 1765, 35: 475 .

${ }^{98} \mathrm{~J}$. Woodward, To do the sick no harm, London, Routledge \& Kegan Paul, 1974; F. N. L. Poynter (editor), The evolution of hospitals in Britain, London, Pitman Medical Publishing Co., 1964; D. Owen, English philanthropy, Cambridge, Mass., Belknap Press, 1965; B. Rodgers, Cloak of charity, London, Methuen, 1949.
} 


\section{R. Porter}

it is odd that a large percentage even of the male labouring population seems not to have been able to swim. But the frequency of mishaps involving water (there are scores of reports of drunken wayfarers stumbling and drowning in puddles and standing water), ${ }^{99}$ and the large number of would-be suicides by water, caused public outcry and led to agitation to spread knowledge of the techniques of revival, such as using tobacco clysters, and to the championing of the Humane Society. This institution received glowing publicity and staunch support in the pages of the Gentleman's Magazine. ${ }^{100}$

Such initiatives are revealing. They show that the spur to action to secure the people's health in Georgian England came at least as much from lay involvement as from pressure from the faculty. They also embody a no-nonsense practicality so characteristic of the mind of the English Enlightenment. ${ }^{101}$ The contrast with the tone of public medical debate in Victorian periodicals is rather revealing. Nineteenth-century articles are frequently shrill, full of dire warnings about the rampancy of disease in society. The nation's health is depicted by nineteenth-century campaigners as being sapped by urban filth diseases, by madness, degeneracy, alcoholism, and venereal disease rampaging through the nation, by the pestiferousness of the lumpenproletariat, by narcotics abuse and quackery. ${ }^{102}$ These Cassandra-like forebodings of deadly peril hardly surface amongst the Georgians. There is rather a confidence abroad that social diseases are manageable, and that improvement lies within man's grasp.

Another prominent index of public attitudes towards health appears in the obituary pages of the Magazine. Unfortunately, the history of the obituary remains obscure; $;^{103}$ and we know little of how the genre emerged in relation to other testaments of the deceased, such as epitaphs, funeral sermons, éloges, and printed memorials. From its inception, the Gentleman's Magazine ran an obituary column, but one initially giving only the barest details of demise. Take these instances from 1731:

12. Robert Bristow, aged 105, at Stamford. [He had lost his Hearing, but had his Sight and other Senses to the last.]

\footnotetext{
${ }^{90}$ Gentleman's Magazine, 1747, 17: 567; 1777, 47: 180. See N. Orme, Early British swimming 55BC-AD1719, Exeter, 1983.

${ }^{100}$ Gentleman's Magazine, 1789, 59: 58-59; 1793, 63: 1074: for praise of the Humane Society see 1775 , 45: 251; 1793, 63: 1074; P. J. Bishop, A short history of the Royal Humane Society, London, 1974.

${ }^{101}$ See Roy Porter, 'The Enlightenment in England', in Roy Porter and Mikulás Teich (editors), The Enlightenment in national context, Cambridge University Press, 1981, pp. 1-18; Roy Porter, 'Was there a medical Enlightenment in eighteenth-century England?', British Journal for Eighteenth-Century Studies, 1982, 5: 49-63.

${ }^{102}$ See, for example, W. Coleman, Death is a social disease, Madison, University of Wisconsin Press, 1982.

${ }^{103}$ See C. Gittings, Death, burial and the individual in early modern England, London, 1984; and for the wider European context, J. McManners, Death and the Enlightenment Oxford, Clarendon Press, 1981; Ariès, op. cit., note 9 above, pp. 78, 161, refers to obituaries only in the Middle Ages. The historical literature on epitaphs similarly relates almost wholly to Classical times. For the literature of éloges, see C. B. Paul, Science and immortality, Berkeley, University of California Press, 1980; D. Outram, 'The language of natural power: the éloges of Georges Cuvier and the public language of nineteenth-century science', Hist. Sci., 1978, 14: 153-178.
} 


\section{Lay medical knowledge in the eighteenth century}

Philip Markham, Esq; at Claxbury in Lincolnshire.

James Earl of Airly, a young Nobleman, lately marry'd to a Daughter of the Lord Dun, in Scotland.

14. Mr. Hughes, Wine-merchant, and one of the Common-Council-Men in Dowgate Ward. Thomas Ereskin, Esq; Brother to the Earl of Buchan, (at Edinburgh.)

16. Edward Fellows, Esq; formerly Master in Chancery, and Brother to the late Sir John Fellows, Bart.

17. Nathaniel Halhead, Esq; a Pattern-drawer in Cornhill, and Exchange-broker. ${ }^{104}$

As time went on, more information was given about the deceased, including character evaluations, life history, family details, etc.; until by perhaps the $1770 \mathrm{~s}$ it was also common to give a line or two-sometimes-on the cause or circumstances of death. These details are, I believe suggestive about contemporary perceptions of illness and its relations to death. Above all, the deceased's entire biomedical profile, the focus of attention in these lengthier obituaries becomes concentrated on the actual circumstances of dying, as is evident in the following examples:

Aged 44, the wife of Mr. Thomas Cobb, of Calthrop-house, Banbury, in Oxfordshire, banker. Mrs C. caught a cold in returning from visiting a friend a few evenings before, and without the least danger being apprehended by the family or their medical friends, sunk away into the arms of death without a sigh, groan, or struggle; one day only was wanting to complete the 20 th year of her marriage. ${ }^{105}$

Suddenly, the Rev. Mr M'Kill, pastor of Bankend, of Duresdeen in Scotland. The manner of his death was very remarkable, and has made an impression upon the minds of his parishioners ... He mounted the pulpit in good health, lectured as usual, and it being the last sabbath of the year, chose for his text these words: "we spend our years as a tale that is told." He was representing, in a very pathetic manner, the fleeting nature of human life, and of all earthly things, when, on a sudden, he dropped down in the pulpit and expired instantly. ${ }^{108}$

In other words, the prime "medical" aspect of the obituary is a narrative of dying: a graphic account of how the living passed over into the dead. Existential trackings of the process of decease of this kind are presented far more frequently than strictly medical explanations are offered of the cause of death. How people came to die is more important than the disease they died of. Of course, fatal diseases or conditions are often enough specified-apoplexy, consumption, and cancer are all prominent-and there is a range of other descriptions occupying the middle-ground between medical labels and common (often conventionally euphemistic) parlance, so that people are often noted as dying after "a long and lingering complaint". ${ }^{107}$ But within the wider moral purposes of the obituary genre, death is not particularly depicted as a medical event (i.e., one in which disease and doctors hold centre stage), though gruesomely graphic post mortem details are occasionally given. ${ }^{108}$

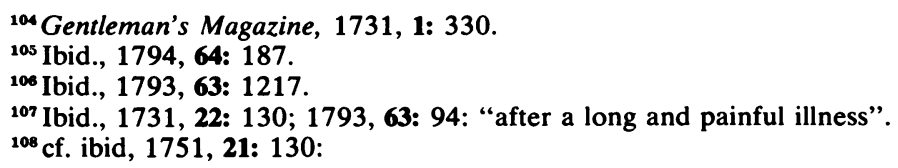

The Opinion of the Physicians and Surgeons concerning the Distemper which occasioned the Death of his late royal Highness the Prince of Wales, on the 20th Instant. 


\section{R. Porter}

This applied to the wider sphere. An impressionistic survey of the first seventy years of obituary notices in the Gentleman's Magazine suggests that it was only very rarely that medicine and medical men were seen as key figures in the circumstances surrounding death. This is not to imply that the sufferers didn't make lavish recourse to doctors and medicine both during their lifetimes, and not least on their deathbeds. Physicians, however, were for fighting distempers and managing pain. With the onset of the drama of the battle with death, there was no automatic and privileged role for doctors. This was not, in England, because the place by the dying man's bedside- as the obituary depicted it-was being occupied by priests. The obituaries make little mention of formal Christian rituals of dying. ${ }^{109}$ Clergymen hardly figure in them at all, and there are no miracles, no deathbed conversions, no providences; even pious last words are few. Religion appears, but it features as part of a broadbacked fortitude, and is lay-centred, emanating from the conscience of the dying man.

The reason why practitioners hardly appear in these obituaries is because they are essentially irrelevant to the two main circumstances under which obituary-column writers described people dying, each of which has its own moral. In the first scenario, certain sufferers die slow, lingering deaths, victims of generally unspecified afflictions (e.g., a "decline"), which medicine cannot halt. Here the obituarist's moral lies in spotlighting the sufferer's emulable virtues in managing his condition: resignation, stoicism, composure, cheerfulness, etc. To take one example-with a nice irony, a dying physician:

At Portsmouth, in his 56th year, Thomas Silver, M.D. for many years in the first practice in that and the neighbouring towns. His disease was lingering, complicated, and exquisitely painful; he was confined to his house, and almost entirely to his bed, more than 14 months; yet he preserved his mind uniformly patient, placid and cheerful. With a perfect knowledge of the daily and rapid progress of his disease, and with the view of death rapidly approaching, he would, immediately after the most acute paroxyms of pain, converse with earnestness and animation. When, for the last few weeks of his life, his debility was so much increased as to disable him, in a great measure, to take any share in conversation, his countenance strongly marked the interest he took in that of his friends. The day before his death he observed that it had pleased God to appoint him a bitter cup of affliction, and that he saw he must drink it to the very dregs; and this, indeed he did. But he submitted to the divine dispensations with that resignation and fortitude which can only be experienced by those who feel the full force of religion on the mind. ${ }^{110}$

On opening the body of his Royal Highness we found all the parts in the lower belly, or abdomen, sound.

The cavity of the thorax was naturally contracted and narrow.

The lungs on the left side were perfectly sound, and without any adhesion to the surrounding parts; the heart and pericardium without distemper.

On the right side upon raising the ribs we found a cyste or bag, situated between the outer surface of the lungs and the ribs, which contained half a pint of very foetid matter. This cyste was about six inches long and four in breadth, extending nearly from the third rib downwards to the seventh. The coats of this cyste were here a quarter of an inch thick, and strong. This was a new distemper, but must certainly have been growing there some considerable time. [etc.]

Such lurid and gross details drew occasional protests: ibid., 1786, 56: 761.

${ }^{109}$ See I. Illich, Limits to medicine, London, Boyars, 1976, ch v, for the secularization of death in the Enlightenment.

${ }^{110}$ Gentleman's Magazine, 1795, 65: 1058. 


\title{
Lay medical knowledge in the eighteenth century
}

Or another, putting the message in a nutshell: "After a lingering illness, which she bore with exemplary fortitude and resignation, Mrs. Richards, wife of Mr. R. Swines-market. Leicester." "111 In suchlike cases, death gradually tightens its grip; there is no tale of heroic medical intervention. On the other hand, at least as frequently, the drama of the narrative lies in death striking right out of the blue, souse in the midst of life. To take some examples:

\begin{abstract}
At Wirksworth, Mr. John Euston, baker. His wife, who was pregnant of her seventh child, was so agitated when she heard the doleful sound of the passing-bell, that she miscarried; and, on the evening of the 4 th, whilst the bell was tolling for the funeral of her departed husband, she expired. ${ }^{112}$
\end{abstract}

At Ramsey, co. Huntingdon, Mr. Thomas Whytell, an exciseman. His death was sudden: being at the Crown Inn there, he complained of a pain in his stomach, and requested the landlord to assist him out of the house, and on coming out he immediately dropped down and expired. ${ }^{113}$

Rev. Marshal Montagu Merrick, L.L.D. lecturer of St. Anne's Westminster, and V. of Ryegate Surrey. He had retired into his library after tea, and staying somewhat longer than usual, the servant went to call him to supper, which was generally roasted apples, and found him dead on the floor and the candle under him.114

Sometimes this form of death has hints of a poignant moral: "At Beverley, while winding up his watch, aged 83. Mr. Lyon". ${ }^{115}$-or occasionally, of just deserts: "At Redruth, in Cornwall, Peter Cox, a miner. He was drinking at the Three Compasses in that town, and, in a fit of inebriety, blasphemed the Evangelists, wished perdition to all the kings of the earth, and drank Tom Paine's health; when, on a sudden, his jaw became locked, and he died on the spot in the most excruciating torments."116 Often Death is a grotesque, cruel absurdity, arising almost from nothing: "Rev. Mr. Joseph Oliver, suddenly, at Bristol from cutting his thumb nail too close." "117 For Death mocks people when most they are alive:

\begin{abstract}
Mrs Fitzherbert, relict of the late rev. Mr. F. of Northamptonshire. On the Wednesday evening before her death this lady went to Drury Lane theatre, in company with some friends to see the Beggar's Opera. On Mr. Bannister's making his appearance in the character of Polly, the whole audience were thrown into an uproar of laughter; unfortunately the actor's whimsical appearance had a fatal effect on Mrs. Fitzherbert; she could not suppress the laugh that seized her on the first view of this enormous representation; and before the second act was over she was obliged to leave the theatre. Mrs F. not being able to banish the figure from her memory, was thrown into hysterics, which continued without intermission until Friday morning, when she expired. ${ }^{118}$
\end{abstract}

In ways that bring to mind volume VII of Tristram Shandy, Death thus eludes the powers of medicine. This is because in so many cases it is caused by an accident-not even a disease, which medicine could at least have a stab at. A high percentage of the fatalities obituarized are the result of clothes catching fire, people falling out of windows, being thrown from horses, carriages spilling, buildings collapsing - minor

in Ibid., 1798, 68: 178.

112 Ibid., 1797, 67: 482 .

${ }^{113}$ Ibid., 1793, 63: 772 .

114 Ibid., 1782, 52: 455 .

${ }^{115}$ Ibid., 1793, 63: 960.

${ }^{116}$ Ibid., 1795, 65: 257.

${ }^{117}$ Ibid., 1765, 45: 495.

${ }^{118}$ Ibid., 1782, 52: 207. 


\section{R. Porter}

disasters in sufficient numbers to warrant the obituary column being divided in its early years into two sections, "Deaths" and "Casualties" (i.e., death by accident). Death struck without warning in all manner of ways:

By a bite in the upper lip from a dog which went mad a few days after, a poor man, named Thomas Austin, of Arnley, near Leeds. He expired in the strongest convulsions of the hydrophobia. ${ }^{119}$

Mrs. Smith, wife of Mr. P. C. S. of Erwarton. She fell into a well near her dwelling house, and was drowned; although she was taken out as speedily as possible, and medical assistance procured, every effort to restore animation proved fruitless. ${ }^{120}$

Aged 84, Jervis Gibson, esq. senior alderman of Lincoln. His death was occasioned by taking poison through a mistake. Having been in the medical line, he used to mix his own medicines; and intending to take some salts, he ordered his servant to bring him a paper out of a drawer, part of the contents of which he mixed in warm water, and after drinking it off, on finding a sediment, he was alarmed, and on examining the paper, found he had taken corrosive sublimate. The proper means were tried without effect, and he died in half an hour. ${ }^{121}$

A child of Tho. King, labourer, at Enfield Highway, drinking a very small quantity of Heslop's preparation for destroying flies (which is a composition of white arsenic and honey) died in two hours in the greatest agonies. ${ }^{222}$

To the melancholy list of sufferers by the rapid spreading of fire, when aided by the light texture of female dress, we have to add the amiable and accomplished Miss Taylor, of Southampton; who, on a visit to her uncle at Newport, in the Isle of Wight, about three months since, standing incautiously too near the fire, suddenly found herself involved in flames, and was so much burnt before they could be extinguished, that, after languishing seven days in extreme misery, Death closed her sufferings. ${ }^{123}$

Of convulsions in her bowels, occasioned by the thunder on Monday morning, Miss Hallam of Islington, dau', of the late Mr. $\mathbf{H}$. dissenting minister.

A Lady at Hammersmith lost her life by the same causes, at the same time. ${ }^{124}$

Not to mention the sad case of Mr. Monro devoured by a tiger. ${ }^{125}$

But alongside accidents, there was another mode of death which defied the doctors: suicide. The Georgians were notorious for their proclivity towards suicide, ${ }^{128}$ - which was, perhaps more myth than reality. But the deaths reported in the Gentleman's Magazine (unrepresentative as they obviously are) certainly give prominence to suicides - and other sources such as coroners' bills seem to confirm they were indeed frequent. ${ }^{127}$ Each month sees a couple of suicides graphically depicted:

Thomas Day, esq. of Portland Place. This gentleman, once amazingly rich, appeared a bankrupt in the London Gazette of Saturday the 22nd of June (as an oilman, dealer, and chapman, of

${ }^{119}$ Ibid., 1794, 64: 386. For a characterization of death at the end of the century, see W. R. Albury, 'Heart of darkness: J. N. Corvisart and the medicalization of life', in Historical reflections/Reflexions historiques, 1982, 9: 17-31.

${ }^{120}$ Gentleman's Magazine, 1794, 64: 168.

121 Ibid., 1786, 56: 372 .

122 Ibid., 1783, 53: 716 .

${ }^{123}$ Ibid., 1795, 65: 355 .

124 Ibid., 1783, 53: 805 .

${ }^{125}$ Ibid., 1793, 63: 671.

${ }^{128}$ See note 86 above; M. MacDonald, 'The inner side of wisdom, suicide in early modern England', Psychol. Med., 1977, 7: 565-582.

${ }^{127}$ For an example see R. F. Hunnisett (editor), Wiltshire coroners' bills 1752-96, Devizes, Wiltshire Record Society, 1981. 


\section{Lay medical knowledge in the eighteenth century}

Blackman-street, Southwark). Unable to bear up against his wayward fate, he, in the forenoon of the 28th, called at an hotel in Covent-garden, took laudanum, and expired in the evening. ${ }^{128}$

Aged 50, Jackson Hernan, esq. of Great Suffolk-Street, Charing-cross, the eldest son of the late Mr. H. formerly an eminent apothecary there. He had been afflicted with an asthmatical complaint for some weeks, and was advised by his physician to change his climate for winter. This advice was so unwelcomed to him that he instantly resolved to destroy himself, and he shot himself through the head. ${ }^{129}$

About 10 o'clock this evening Mr. Robinson, an army-surgeon, put a period to his existence at the lodging of a friend, in Fleet-street. He went upstairs on a sudden, shut the door, and discharged a pistol against his temples, which blew his head to pieces. From the conduct of the deceased previous to the commission of this dreadful deed, it is supposed he acted from the impulse of a sudden mental derangement. ${ }^{130}$

Indeed, the flood of felo de se led to animated discussion in the pages of the Magazine, divided between a majority "soft line" who argued that the laws making suicide a felony were inhumane and needed liberalization; and a minority view seeking tougher penalties (e.g., the anatomization of suicides' corpses) as a deterrent. ${ }^{131}$

Overall, however, the very existence of the obituary column was a monthly tribute to Death's empire. Death held sway because of the ubiquity of accidental and sudden death, because of death from causes beyond medical control, and not least through self-destruction. Though doctors and medicine had their places in life, death was another. matter altogether. In fact, the obituary notices sometimes specifically emphasize how the time will come when medicine can be of no avail. For example:

Between five and six o'clock in the evening in an apoplectic fit, Mr. John Bull, writing-master, \&c. of Air-street, Piccadilly, he was found, fallen down head foremost, on his face, into a dry ditch near the double post by Grimwood and Co.'s nursery, Hogmore lane, at which, it is supposed, he was endeavouring to catch, to support himself. By falling so fatally, he was suffocated by the suffusion of blood in the throat; so that, though a surgeon came, and used the lancet, too late was human aid. ${ }^{132}$

At the Bell at Bromley, in his 45th year, Mr. William Poynder, of Great East-cheap. His death was occasioned by having been thrown from a chaise the week before, by which unhappy accident his leg was broken, which, though immediately set, and the best advice procured, ended fatally, to the great affliction of a large class of friends and acquaintance. ${ }^{133}$

Occasionally, the dying man even pointed the moral himself: "Suddenly, at Oswestry, Mr. Harrison, supervisor of excise in that town. Just before he fell he exclaimed ' $O$ Lord! how suddenly I am struck! all medical skill and assistance is useless!' "'134

The moral of these obituaries was not to argue the case for therapeutic nihilism, or to rail at the ineptitude of the faculty. Indeed, the desire to preserve life was strong, as is evident in the occasional pathetic pharmaceutical postscript to an obituary:

${ }^{128}$ Gentleman's Magazine, 1793, 63: 674.

129 Ibid., 1793, 63: 90.

${ }^{130}$ Ibid., 1800, 70: 695 .

${ }^{131}$ Ibid., 1737, 7: 389-390; 1749, 19: 341; 1751, 21: 464-465; 1754, 24: 595; 1798, 69: 173; 1789, 59: 252.

${ }^{132}$ Ibid., 1795, 65: 438.

${ }^{133}$ Ibid., 1798, 68: 447.

${ }^{134}$ Ibid., 1792, 62: 869. 


\section{R. Porter}

Mr Timerblin, a Gardener, at Chelsea, died by the Bite of a mad Dog this Month; also a Lad in Suffolk, tho' both several Times dip'd in the Sea; therefore it may be of Service, on this Account, to mention, that there is a Powder of Dr Mead's, sold by the Apothecaries, which is a Specifick against such Misfortunes, was never known to fail.-The following Powder, with the Use of the Cold Bath, cold Spring, or River, is likewise recommended for the same Purpose, having lately cured Mr Wm Goss of Outwell in the Isle of Ely.

(Having washed the blood from the Wound) of Ash-coloured Ground Liver-wort, reduced to Powder 10 Drachms, of Black Pepper, beaten to 4 Drachms. Mix and divide them into 6 parts, and take one every Morning in half a pint of warm Milk). ${ }^{135}$

Indeed, obituaries often pointed out how fatalities might have been avoided. But the solution envisaged is not more and superior medical intervention but prevention, care against accidents, and improved personal regimen. For instance, people were instructed that if their clothes caught fire, the remedy was not to run through the streets, but to roll themselves up in a carpet; similarly, care should be taken not to catch cold. Cold, of course, was regarded as one of the key threats to health in humoral medicine. ${ }^{138}$ Cold prevented sweating (i.e., the salutary expulsion of toxic fluids), and so was thought to clog the constitution-a view particularly conspicuous in Samuel Pepys' diary; ${ }^{137}$ and the obituary columns bulge with those who by their own carelessness brought on colds and thus hastened their exit. For instance:

\footnotetext{
Mr. Thomas Bunter, a respectable farmer, of Cheddon-Fitzpain. Returning from his grounds, where he had been with his labourers, much heated, he went to this cellar, and drank only one pint of cider, which soon occasioned a violent pain in his bowels, of which he languished till morning. ${ }^{138}$

Of a cold, caught by being in the rain, aged 71 , Peter Roberts esq. remembrancer of the city of London, and formerly comptroller of the Bridgeyard; which later office he had resigned in 1791 , on being allowed an annuity from the city. ${ }^{139}$

Miss Elizabeth Richardson, daughter of Mr Robert R. of the Six Hundreds in Heckington fen, co. Linc. She had been dancing a few evenings before; and the cause of her death is supposed to have originated from drinking cold water or small beer, and going in to the air before she was cool..$^{140}$
}

To be weighed against these dire warnings were the success stories. The obituary columns parade many paragons of longevity; and the obituarists again generally point the self-help moral: moderation, low diet, labour:

At his house in York Street, Westminster, aged 94, Mr Charles Cruse; of whom it is worthy of record, that, having some years since been afflicted with the stone and gravel; he wore out the disease by temperance and a strict adherence to diet, which had been chiefly vegetable for $\mathbf{4 0}$ years. ${ }^{141}$

At Worlingworth, Suffolk, Mr J. Wilson, Aged 116. His suppers, for 40 years past, were roasted turneps. ${ }^{142}$

At Preston, near Hull, Val. Cateby, who attained to the great age of 116, and had his intellects

${ }^{135}$ Ibid., 1735, 5: 163.

${ }^{136} \mathrm{Cf}$. Helman, op. cit., note 2 above.

${ }^{137}$ See Porter, op. cit., note 2 above.

${ }^{138}$ Gentleman's Magazine, 1793, 63: 771.

${ }^{139}$ Ibid., 1793, 63: 1054

${ }^{140}$ Ibid., 1794, 64: 189; cf. 1798, 68: 544.

${ }^{141}$ Ibid., 1793, 63: 773.

${ }^{142}$ Ibid., 1782, 52: 503. 


\section{Lay medical knowledge in the eighteenth century}

perfect till within two days of his dissolution. His diet for the last 20 years was milk and biscuit. ${ }^{143}$

Though, as if to remind us that the eighteenth century was the age of excess, this also slipped in: "In the neighbourhood of Newcastle, aged 100, James Palmer; who, for the last 30 years of his life, never went to bed sober." 144

What do these obituaries collectively tell us? Above all, however much medicine may have been infiltrating into other theatres of life, they show little trace of the medicalization of death. Illich has characterized the Enlightenment as the period when doctors commenced their secular joust with death, promising emancipation from its clutches, remarkable longevity, and even immortality. Such may have been the aspirations of an intellectual élite-men such as Erasmus Darwin, Godwin, and Condorcet. ${ }^{145}$ But there are no signs of such medical Promethianism in these obituaries. Death, after all, was not about specific pathogens, against which medicine engaged in mortal combat; rather, it was either the natural running down of the system, burning out the wick of life, or it was a bolt from the blue. In neither case was physic of much use; death was not a heavily medicalized event.

It is verging on platitude to state that in the pre-industrial age the public possessed a rich heritage of medical lore and practised extensive self-medication. Indeed, as Jewson has argued, it was this very fact which itself helped to shape professional medicine in the Georgian period. Yet little attention has hitherto been given to the channels by which this knowledge was diffused and reproduced. In trying to account for this medical knowledge amongst the laity, we might be tempted by two misleading models. On the one hand we might see the medical interests of laymen as essentially personal, the concerns of those who for some private reason (such as individual affliction) took up the study for remedy or consolidation. Or, on the other hand, we might take it for granted that lay medical praxis was essentially a residue of folk, oral, traditional culture, which was becoming threadbare, being suppressed, or was being driven underground by the march of science and professional hegemony during the Age of Enlightenment, paralleling the fates suffered by popular sports, superstitions, festivities, and calendar celebrations. ${ }^{146}$ The evidence contained in the Gentleman's Magazine, however, should lead us to question both these interpretations. For as well as demonstrating the continuing strength and dexterity of public involvement with medicine, the Magazine also seems to show that being familiar with medicine was not an individual and private matter, but integral to the public role of the well-informed, public-spirited, and responsible layman. Furthermore, active medical engagement was far from being confined to plebeian culture. In the Georgian period, lay medical culture was not in opposition to the physic of the practitioners, nor was it being threatened or suppressed by them. ${ }^{147}$

${ }^{143}$ Ibid., 1782, 52: 503.

144 Ibid., 1798, 68: 172.

${ }^{145}$ See Porter, op. cit., note 101 above.

${ }^{146}$ Cf. R. W. Malcolmson, Popular recreations in English society, 1700-1850, Cambridge University Press, 1973; E. P. Thompson, 'Patrician society, plebeian culture', J. soc. Hist., 1974, 7: 382-405; B. Bushway, By rite. Custom, ceremony and community in England 1700-1880, London, 1982.

${ }^{147}$ For the shortcomings of two-culture stratification models see P. Burke, Popular culture in early modern Europe, London, Temple Smith, 1978; idem, 'Popular culture in seventeenth-century London', 


\section{R. Porter}

Rather, the laity had a substantial stake in forms of medicine which overlapped and interacted with professional medicine; lay medicine was, and remained, active and adaptable. It is not until the nineteenth century that we can properly identify powerful lay-directed movements which deserve to be styled "fringe", or "alternative" medicine, defining themselves in opposition to the orthodoxy of the faculty. ${ }^{148}$

I have been suggesting that the first seventy years of the Gentleman's Magazine offers a picture of medical knowledge diffused throughout the public domain, with extensive lay participation and no insuperable boundaries between lay and professional. Endorsing Jewson's analysis, I believe that this situation was special to the eighteenth century. This impression is confirmed if we glimpse forward to the changing place of medical matters in the Gentleman's Magazine in the nineteenth century, where we see changes which reflect both real shifts in the relations between the medical profession and the laity, and also changing public expectations as to the roles which miscellanies such as the Gentleman's Magazine could (or could not) fulfil in publicizing medicine. ${ }^{149}$

To some degree, the medical coverage of the Magazine continued into the nineteenth century much as before. For instance, the bills of mortality continued to be routinely printed, and the book reviews section still gave prominence to often detailed accounts of specialized medical books and pamphlets. And overall, much space was still given over in the first half of the nineteenth century to medical issues. But their nature changes considerably.

From about the 1810 s in particular, there was a dramatic decline in the exchange of medical advice, inquiries, remedies. The Magazine clearly ceased to play any important role in instructing the laity in medical self-help or as a medical talking-shop. By contrast, for example, to the publicity given by the Magazine to the voluntary hospital movement in the previous century, there is little sign that the Gentleman's Magazine was any longer helping to stimulate the broadcasting of lay medical initiatives. The reports of medical charities are rather few.

Instead, the bulk of the medical insertions were then typically reports on what the medical profession was doing, viewed as an organized profession. The proceedings of metropolitan medical societies were faithfully reported, and lengthy accounts

London Journal, 1977, 3; Payne, op. cit., note 11 above, pp. 3-33; R. Muchembled, Culture populare et culture des élites Paris, Flammarion, 1978. For methodological discussions see C. W. E. Bigsby (editor), Approaches to popular culture, London, Edward Arnold, 1976; R. Samuel (editor), People's history and socialist theory, London, Routledge \& Kegan Paul, 1981, pp. 216-240; R. Johnson, 'Three problematics', in J. Clarke, C. Critcher, and R. Johnson (editors), Working-class culture, London, Hutchinson, 1979, pp. 201-237.

${ }^{148}$ See J. Whorton, Crusaders for fitness, Princeton University Press, 1982; G. Risse, Medicine without doctors, New York, Science History Publications, 1977; A. C. and M. Fellman, Making sense of self, Philadelphia, University of Pennsylvania Press, 1981; R. Wallis and P. Morley (editors), Marginal medicine, London, P. Owen, 1976; J. V. Pickstone, 'Establishment and dissent in nineteenth-century medicine', in W. J. Sheils (editor), The Church and healing, Oxford, Basil Blackwell, 1982, pp. 165-190; and L. Barrow, 'Anti-establishment healing; spiritualism in Britain', in ibid., pp. 225-248.

${ }^{149}$ As I hope to discuss these changes in the Magazine in the nineteenth century in greater detail in a subsequent article, I shall not document them here in these footnotes. 


\title{
Lay medical knowledge in the eighteenth century
}

appeared of the medical politics surrounding public issues such as the passing of the Apothecaries' Act (1815), and the formulation of public health policy in the 1830s and 1840s. Gentleman's Magazine readers were thus being given a window on to the world of the medical profession and medical politics, but it was a world in which they were no longer expected to participate. It may also be significant that idealized accounts of prominent physicians' careers began to appear in the obituary columns. It seems likely that this shift in medical coverage faithfully reflects shifts in lay-professional relations during the course of these generations.

A seal was set on lay exclusion by a major policy shift in the Gentleman's Magazine which occurred between 1847 and 1849. Till then, the periodical had been a miscellany, with a genuinely catholic range of interests. In 1849 , however, the management announced that the growing division of intellectual labour and specialization of the age no longer left that editorial policy viable; henceforth the Magazine would concentrate essentially on literary and antiquarian topics. Thus, from the mid-nineteenth century, medical matters disappeared from the Gentleman's Magazine altogether. This did not signal, it goes without saying, the end of lay medical culture; but it does represent the severing of one long-established artery through which lay and professional medical interests intermingled.

The Gentleman's Magazine was thus an important medium for Georgian medical views, serving both as a receiver and a transmitter, amplifying here, perhaps distorting there, picking up and propagating signals. It deserves further study, and in particular alongside other periodicals and similar comparable bodies of evidence. For it must not be forgotten that it catered only to one sector of society, and above all, quite explicitly, only to one sex. In no sense was it the sole accredited vox populi. Before our ears can be properly tuned to the polyphonous voices of lay medicine, much further research of this kind needs to be done.

\section{ACKNOWLEDGEMENT}

Grants from the Wellcome Trust during the summers of 1982-84 have provided me with research assistance without which this study could not have been brought to fruition. I wish to express my gratitude for these. Stephen Marriage, Fi Godlee, and Christiane Harris acted as research assistants. I wish to thank them for their eager, intelligent, and cheerful work.

\author{
APPENDIX (pp. 166-168) \\ TABLE OF PROPRIETARY MEDICINES (Pharmacopoeia Empirica)
}

(Gentleman's Magazine, 1748, 18: 348-350) 


\section{R. Porter}

348 Tbe Gentleman's M AGAZINE. Vol. XVIII: PHARM A COPOEIA EMPIRICA, or the LIST of NOSTR UMS and EMPIRICS.

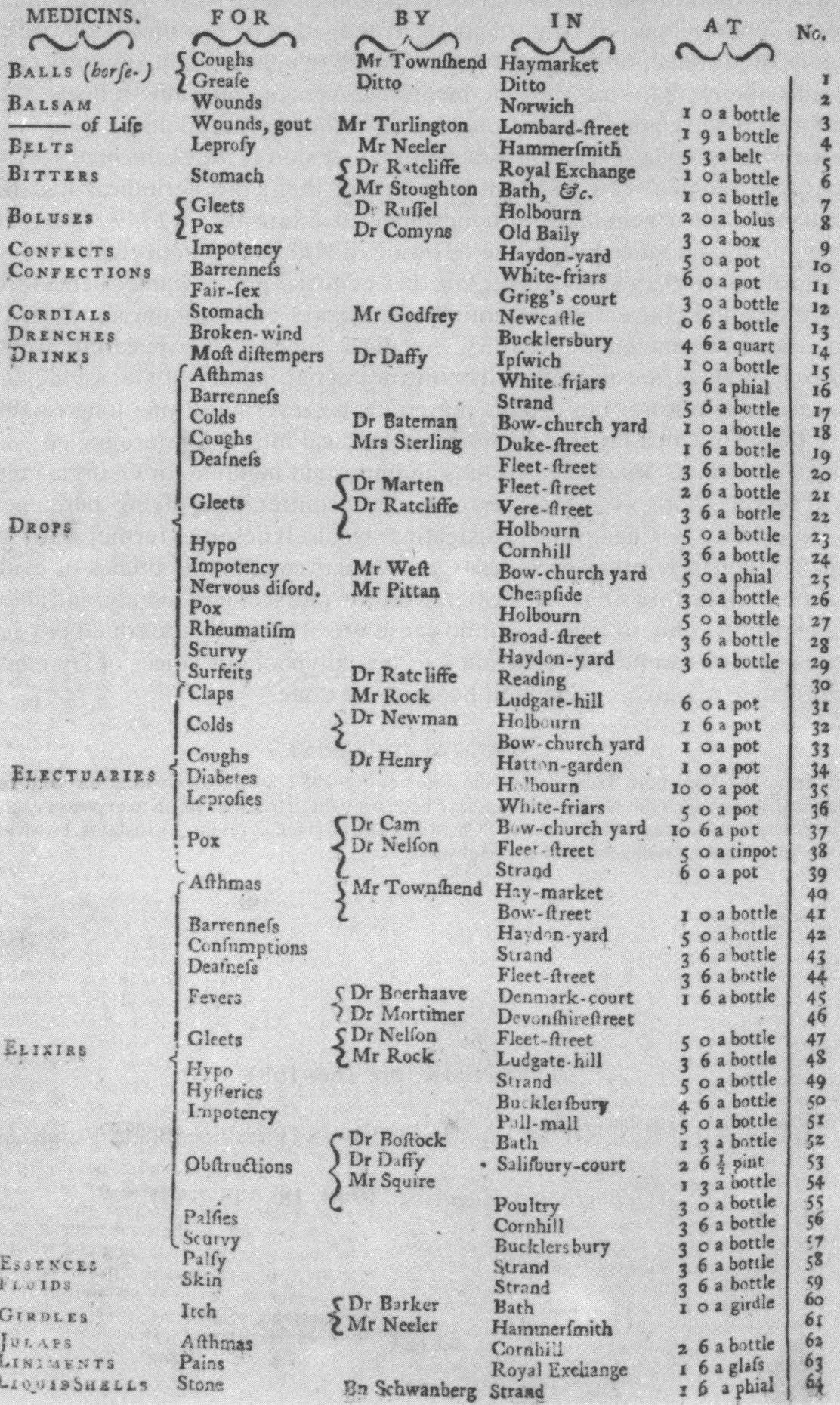




\section{Lay medical knowledge in the eighteenth century}

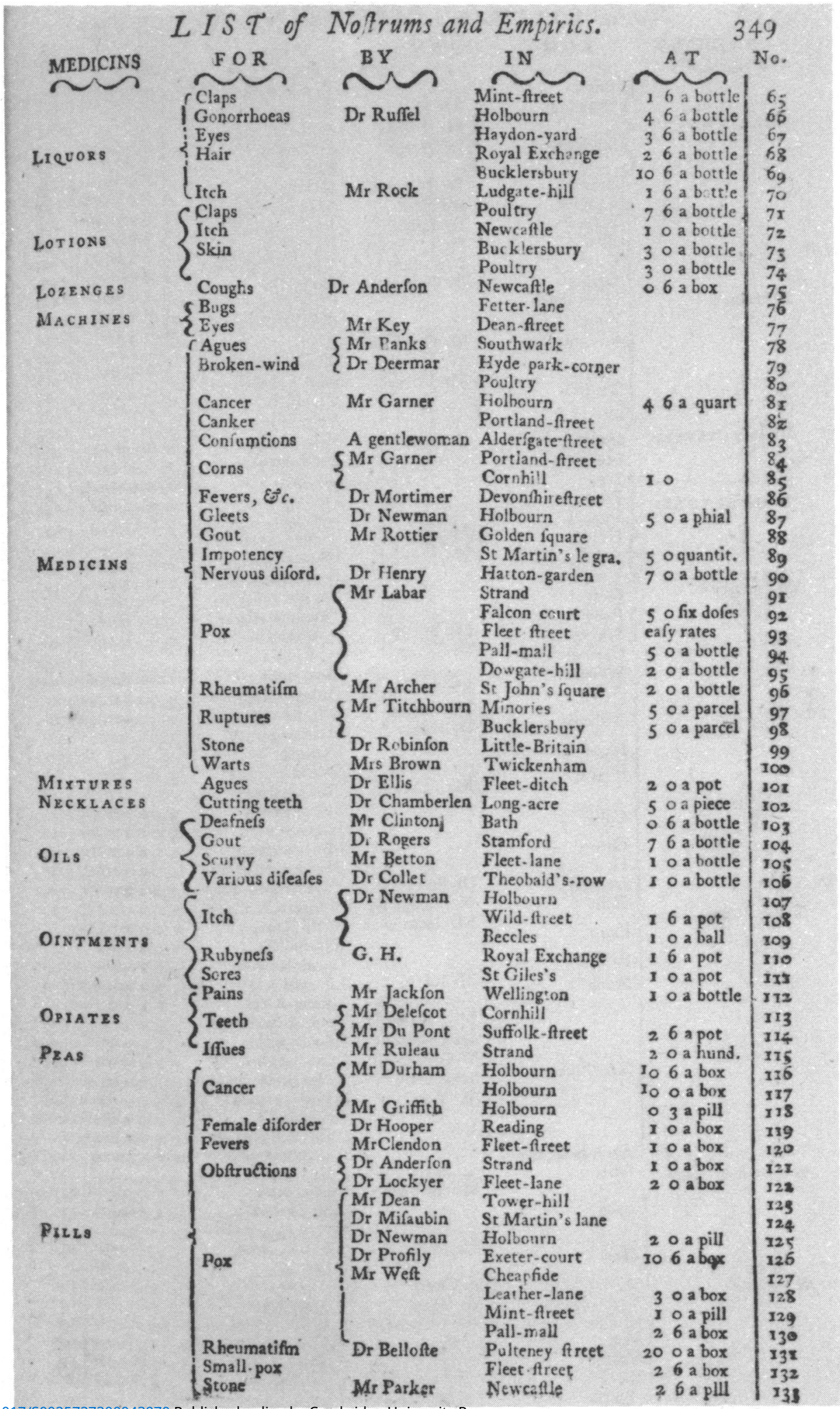




\section{R. Porter}

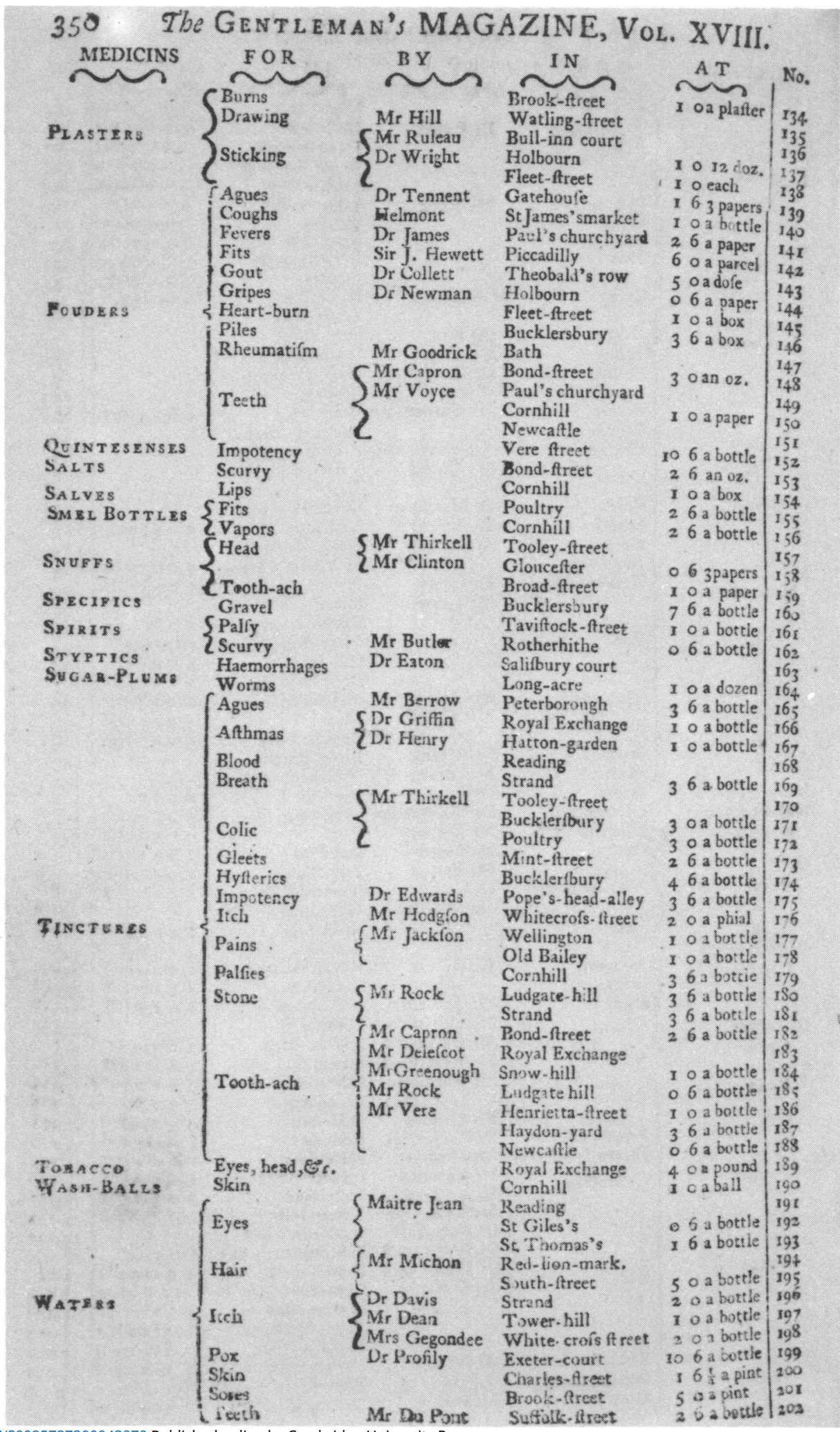

